\title{
Native fish conservation in Nepal: Challenges and opportunities
}

\author{
Tek Bahadur Gurung \\ Nepal Agricultural Research Council, Singh Durbar Plaza, Kathmandu, Nepal \\ E-mail: tek_fisheries@hotmail.com
}

\begin{abstract}
Habitat degradation and loss probably has been more responsible for the decline of native fish species. Nepalese fishes are one of main aquatic vertebrates which are yet to be studied for their occurrence, distribution and ecology, especially from western regions of the country. However, before complete understanding on native fishes, threat over their existence have been loomed by climate change, over fishing, pollution, alteration of natural habitats and poor understanding of fish ecology etc. Thus, publicizing the importance and knowledge of fish conservation has been one of the most important challenges. The other challenges are sustainability of quality and quantity of freshwaters which have been impacted. In such circumstance to overcome the problems, adoption of community or cooperative based conservation could be one of the best approaches for freshwaters and fish restoration. Optimistically, a national strategy on conservation of freshwater fish is desirable. Fish conservation has the opportunities to be used for multidimensional purposes. A success of single fish species might contribute substantially on local economy, if that could be used in aquaculture or angling for tourism industry.
\end{abstract}

Key words: Anthropogenic activities, native fish, cooperative based conservation

\section{Introduction}

Freshwater fishes are one of the most ignored fauna for conservation, as a result alarming decline in fish diversity persist (Jana, 2007; Shrestha et al., 2009), especially in urban and southern region of Nepal. The native fish decline is associated with poor knowledge, priority, investment; and water quantity and quality (Shrestha, 2011; Gurung \& Baidya, 2012). Cowx (2002) indicated that anthropogenic disturbance and ignorance are the most important factor for decline and extinction of fish worldwide.

Fishes are considered auspicious and symbolize as sign of fertility, power and prosperity in Nepal. The native fish diversity including endemic one's have been reported by Shrestha (120 species in 1981 and 206 species in 2011), Rajbanshi (181 species in 1982 and 187 species in 2005, and T.K. Shrestha (227 in 2007 and 202 species in 2008). Such fishes weighing more than $40-50 \mathrm{~kg}$ or more individually belonging to cyprinidae and siluridae, are common (Gurung, 2003). Fishes become more vulnerable, and threatened by inequitable protection measures comparing to wild terrestrial mega animals (Pascual et al., 2002; Gibson \& Pullin, 2005). For enhancing native fish conservation; general awareness, inclusion of academic courses in education system might be useful. This paper aims to elucidate present status, knowledge gaps posing challenges on native fish diversity and opportunities for conservation. 


\section{National strategy on fish conservation}

Fish conservation is the part of National Biodiversity Conservation Strategy of Nepal (HMG/MFSC, 2002). According to the biological diversity convention 1992, forest ecosystem, wild life habitats and genetic resources were committed to be conserved through national protected area system covering about 19\% area of the country (MFSC, 2006). This strategy claimed to conserve all fauna and flora, however, fishes were largely ignored, probably due to poor advocacy on fish conservation causing rampant fish diversity loss. As an example, description on conflict between fish dependent communities and administration in Chitwan National Park (Jana, 2007) explains the fact on fish conservation.

For conservation of aquatic animals including fish, the government has promulagated "Jalchar Samrachhan Ain 2061" (Aquatic Animal Conservation Act 2061 with amendment 2057). The Act prohibits indiscriminate killing of fish and aquatic animals by unconventional methods. According to the amendent Act, construction of hydro or irrigational dam or barrages must be incorporated by fish ladder or fish hatcheries to compensate the loss of aquatic life. The government has also promulgated the regulatory ordinance for capturing of certain species, size and seasonality of native fish. According to the ordinance certain fish has been banned to be captured during the spawning season.

Often native fishes are blamed to be not economical for cultivation. Contrastingly, it has been shown that technological innovations could be rapid, if research focus could be given on native fish. For example, in Kali Gandaki Fish Hatchery as designated research station for native fish, at present nine native fishes has been bred in captivity successfully (KGFH, 2005-06). As an output, the station produces about one million fingerlings of native fishes for restocking in regulated rivers (Gurung \& Baidya, 2012). This knowledge on native fish spawning has the implication on sustainable renewable hydropower development and economic growth of the country.

\section{Basic fish taxonomy}

In order to achieve conservation goals a sound knowledge of taxonomy for recognition of correct species is highly desirable (Lysne et al., 2008). On Nepalese fish fauna prelimanary studies on fish taxonomy and nomenclature has been occurred. Jeevan Shrestha has published a record of 120 fish species from Nepal (Shrestha, 1981). Besides, Ng and Edds (2004), Rajbanshi (2005), Edds and Ng (2007), Shrestha (2007) have given account on Nepalese fish fauna. Proabably the largest collection of identified native 127 fishes in the country is in the museum at Godawari Fish Farm (Nepal Agricultural Research Council). Several authors have also shown new record of fishes, however, most of them are compilatory. The most recent work is a compilation of 227 fishes in Nepal.

These works are not free of synonimical errors, duplication cotroversies and inconsistent nomenclature theories. Inappropriate nomenclature hinders to identify fishes correctly. The conservationist may not be necessarily be a taxonomist. Since, correct identification of fish enable conservationst to work efficiently to pass the accurate inoformation easily (Lysne, 2008), so comprehensive knowledge on fish taxonomy and identification is highly desirable to reveal unrecorded new native fish before they might peril and extinct. 


\section{Fish ecology}

Nepal is a country having an altitude from $60 \mathrm{~m}$ elevation to world highest peaks of $8848 \mathrm{~m}$. In this altitudinal range fish has been recorded from upto $3600 \mathrm{~m}$ elevation (Rajbanshi, 2005). It is anticipated that there should be fishes on greater altitude also. Fishes are specific in distribution exhibiting specificity for cold or warm waters. Such a pattern suggests specific adaptation and physiological status of species for dissolved oxygen, temperature, torent, lentic and lotic habitats (Gurung, 2011). Indeed, Nepal is a natural laboratory to understand morphological and physiological variations in organisms in relation to altitudinal changes (Gurung et al., 2011b).

\section{Conservation Challenges}

Contribution of native fish to total production is declining worldwide, as most fishes have been over fished (Allan et al., 2005; Allen et al., 2010). Previously, many non-native fish for enhancing aquaculture; and protect native fish by diverting consumption to non-native species were encouraged (Gurung, 2007; Gozlan, 2008). For measuring what extent those strategies contributed to native fish conservation, detail scientific analysis might need to clarify. It is also imperative to examine which factors are likely threatening native fish biodiversity? Some of the major factors which might threatened the native fish diversity could be delineated as given in table 1. Some of major challenges imposing threat to native fish conservation included:

Table 1. List of major anthropogenic and natural threats to native fishes of Nepal.

\begin{tabular}{|c|c|c|c|}
\hline \multirow{2}{*}{ Factors } & \multicolumn{3}{|l|}{ Effects } \\
\hline & Negative & Positive & Overall rating \\
\hline $\begin{array}{l}\text { (A) Anthropogenic } \\
\text { (such as damming, } \\
\text { change in eco } \\
\text { physiological state) }\end{array}$ & $\begin{array}{l}\text { Fish requiring migration, } \\
\text { high transparency, high } \\
\text { dissolved oxygen and } \\
\text { flowing water should be } \\
\text { declined }\end{array}$ & $\begin{array}{l}\text { Fish adoptable to low } \\
\text { oxygen, low } \\
\text { transparency and } \\
\text { stagnant water may } \\
\text { flourish }\end{array}$ & $\begin{array}{l}\text { In general, native fish } \\
\text { diversity should decline. }\end{array}$ \\
\hline i. Eutrophication & $\begin{array}{l}\text { Fish community shift, } \\
\text { cline in fish requiring } \\
\text { clean water. }\end{array}$ & $\begin{array}{l}\text { Supportive to fish } \\
\text { species adoptable to } \\
\text { survive in eutrophic } \\
\text { waters. }\end{array}$ & $\begin{array}{l}\text { In general fish diversity } \\
\text { should decline with } \\
\text { those thriving well in } \\
\text { clean water }\end{array}$ \\
\hline $\begin{array}{l}\text { ii.Unconventional } \\
\text { fishing }\end{array}$ & $\begin{array}{l}\text { Fish diversity decline } \\
\text { and lost }\end{array}$ & & $\begin{array}{l}\text { Should declined the } \\
\text { overall aquatic diversity }\end{array}$ \\
\hline iii. Introduction & $\begin{array}{l}\text { May compete with } \\
\text { native species, as a } \\
\text { result there should be } \\
\text { advantages to competent } \\
\text { fish }\end{array}$ & $\begin{array}{l}\text { May provide additional } \\
\text { fish species for } \\
\text { cultivation }\end{array}$ & $\begin{array}{l}\text { Depend on the type of } \\
\text { the introduced fish. In } \\
\text { general there should be } \\
\text { competition with native } \\
\text { fish }\end{array}$ \\
\hline $\begin{array}{l}\text { (B) Natural } \\
\text { i. Climate change }\end{array}$ & $\begin{array}{l}\text { Several warm water } \\
\text { fishes perform better in } \\
\text { deeper mountains due to } \\
\text { increase in water } \\
\text { temperature and } \\
\text { eutrophication }\end{array}$ & $\begin{array}{l}\text { Cold water fish zone } \\
\text { may recede towards } \\
\text { more higher altitude, } \\
\text { and many of the earlier } \\
\text { zone will be unsuitable } \\
\text { for cultivation }\end{array}$ & $\begin{array}{l}\text { In general, should } \\
\text { negatively impact to } \\
\text { native fish population } \\
\text { due to drought and } \\
\text { flood, warming up and } \\
\text { cooling }\end{array}$ \\
\hline
\end{tabular}




\section{Water quality and quantity}

Climate change, habitat loss, pollution, deforestation, siltation, intensive agriculture, littering, road construction, barrages, dam for irrigation, hydropower, sewage, removal of boulders and pebbles from river bed might cause water quality and quantity alterations. Thus, impacting fish habitat and fish decline in rivers, lakes and other water bodies (Gurung, 2007; Jha et al., 2007).

\section{Nuisance species}

Generally, all fishes are consumable in Nepal. So regardless of the taste, size and appearance, fish serves the purpose of food. However, there are certain introduced fishes which have been blamed causing competition for space, food and other resources. There are studies advocating that fish introduction is beneficial as they provide means of livelihood (IDRC, 2007; Gozlan, 2008). Recently, a number of fish used in aquaculture have been reported contributing significantly to food production with significant social impacts but without hampering on native fish biodiversity loss. It was agreed to consider such species as 'naturalized species' (IDRC, 2007). These species could be taken positively contributing in national, regional and local economy (Gurung, 2005) but poses to be the potential nuisance fish in long run, if taken as 'trash' but not as food fish.

\section{Dam for hydropower and irrigation}

In near future, hydropower and irrigational dams with interference to conservation of fish and fisheries would be challenging. In Nepal, electrical power has high demand, since Nepal is rich in river water resources; therefore hydropower generation probably is the best option economically and socially. However, the damming operation would require harmonious technologies to sustain fish diversity (Jha et al., 2007). So development of appropriate technologies would be challenging for native fish conservation.

\section{Climate change}

Climate change is a great threat to aquatic environment (Wagle et al., 2011). Nepal has been rated as $4^{\text {th }}$ most vulnerable countries of the world despite of the fact that contribution of Nepal for climate change is only $0.025 \%$ (Gurung et al., 2011a). Fish habitat shift due to climate change in upper high hills has been expected (Wagle et al., 2011). The climate change has threatened to artisanal fishing communities representing 'the poorest of the poor of the world' in Nepal. Among fishing depended fishers, majority are women (IUCN, 2004; Thapa \& Dahal, 2009). Therefore, fish conservation has been also challenging to livelihood of ethnic women.

\section{Opportunities for success}

Capture fisheries contributes approximately 0.5 of total GDP which is most likely to be contributed by native fishes. This suggests there are enormous opportunities in native fish conservation. Recently six new fish species have been reported as new record from eastern Nepal (Thompson, 2009). Native fishes from western and far western development regions have been known least, despite of huge freshwater resources such as Mahakali river system with network of many tributaries and lakes. So, it can be predicted there should be more new fish species waiting to be discovered and reported in near future.

There are several native fish species considered as suitable candidates for inclusion in aquaculture. Nepal has achieved substantial progress on technological development of 
native fish breeding and rearing (Gurung et al. in press; KGFH, 2005). Due to recent technological innovations desirable number of fry of several native fishes including, Sahar (Tor putitora), Asala (Shizothorax richardsoni), Gardi (Labeo dero) and at least 6 other native fishes in hatcheries could be produced (KGFH, 2005). Some of importance of native fish for cultivation could be outlined as given in box 1 .

Box 1. Values of local fishes for cultivation.

- Preferred locally,

- Less chance of introducing disease,

- Should grow better under local conditions,

- Contribute in biodiversity,

- Maintain integrity in aquatic communities and ecosystems

- Potential for poverty alleviation by promotion of angling, based ecotourism, aquaculture

- Food fishes

- Ornamental fishes

- Sport fishes

- Medicinal value

- Contribution of indigenous fish to national fish production approximates $43 \%$.

- Capture fisheries involve about 427000 active members and the number of direct beneficiaries approximates 580000 peoples.

- It is estimated that about $6.6 \%$, of the 6496222 economically active populations in agriculture sector (CBS, 2006), engaged in capture fishery.

In Nepal, few government organisations, universities and institutions are focusing on fish taxonomy and conservation studies. At present, Tribhuvan University teaches the courses related to fish taxonomy, biological and socio-economic aspects of capture fishery. Kathmandu University on environmental sciences, Nepal Agricultural Research Council has been involved promoting native fish conservation and development of innovative and adaptive technologies (NARC, 2011). Some foreign universities and international agencies are also contributing on enhancing knowledge on fish taxonomy (IUCN, 2004; Edds \& Ng, 2007; Thompson, 2009). These are indications showing the native fish inventory needs to be stabilised with further scope and opportunities of discoveries on fish and fisheries in Nepal. The scopes of native fish conservation could be outline as follows:

\section{Technologies of in-vivo, in-situ, ex-situ conservation or gene banking}

Several modern conservation technologies have been evolved (Edds \& Ng, 2007; Ng \& Edds, 2005a, b). One of the most advanced is gene banking of genetic materials (Bart, 2002). These technologies have been applied in fish conservation in several countries. Introduction of in-vivo technologies in fish conservation would be challenging. Ex-situ conservation technology of some fishes has been initiated. The fish hatchery established by Nepal Electricity Authority in Beltari Synagja, operated by Nepal Agricultural Research Council has been credited to develop the ex-situ breeding methods of some common native fishes (KGFH, 2005). By the law, hydropower and irrigation facilities must promote fish ladder and native fish hatcheries for biodiversity purpose, however, monitoring and evaluation mechanisms of such facilities might be challenging for quality assurance (Jha et al., 2007). To resolve such issues, it has been felt that there should be organizations to monitor the implementation of fish ladder, trapping and hauling, compensatory riparian flow, and provisions of hatcheries in regulated waters. Fish conservation in the plan and 
policies has hardly been prioritized (APP, 1995). Such ignorance will cause fish diversity loss. It is clear that a 'center of excellence' should be initiated to keep vigilance on fish diversity conservation activities in Nepal.

\section{Social mobilization}

To control over destructive fishing (poisoning, use of dynamites and electro fishing, use of small mesh size net), increasing awareness, law enforcement have been challenging. Few years before initiatives of fish conservation by mobilizing local communities, especially women has been encouraged and prioritized (Gurung, 2003). It might be still commendable, if such approach of fish conservation could be continued and supported by plan and policies.

\section{Inter sectoral coordination for fish conservation}

National Planning Commission is the responsible institution for policy formation and coordination among different line ministries. Fish conservation, related to several ministries, for example, agriculture, tourism, irrigation and energy are closely related. However, such co-ordination is weak at present. It has been assumed that weak coordination is also one of the reasons of declining fish conservation. Establishment Fish Sanctuaries and Fish Ranching Centers in co-ordination with Department of National Parks and Wildlife, IUCN, WWF, ICIMOD, Nature Conservation Trust etc could be helpful in native fish conservation and people depending on fishery for livelihood. The Aquatic Life Protection Act 2017 was promulgated in 1960. But its implementation is not effective due to lack of rule and regulation and working procedure. It is therefore, a challenge to bring out the rules and working procedure of the Act.

Currently, there have been thousands of farmers cultivating African cat fish (Clarias gariepinus) in Nepal. To replace non native fish farming by encouraging native fish farming technologies would be a big challenge as the food fish demand is ever increasing.

\section{Conclusions}

The current degradation in native fish conservation might be challenging not only to fish diversity but also impact over food security and income of several million people dependent on fishing. Economic development is likely to degrade the native fish biodiversity due to increased anthropogenic activities. Therefore to ensure native fish conservation significant improvement in law enforcement with high level of wisdom is prerequisite.

The information flow on fish diversity is scanty and limited in the country. In such a gap of knowledge on fish diversity, it is advisable to have government plan, school syllabus, so the knowledge on fish taxonomy and conservation could be prioritised. To address the conservation challenges, it is advisable to establish community or cooperative based conservation groups that have similar interest, expertise, and ability to collect, review and disseminate information to those individual or agencies that could develop and drive natural resource policy of fish conservation. As an opportunity of success, a single fish species might change the face of economy of the country, if that could be used in aquaculture or angling for tourism industry. In general, to conserve the fish and their habitats, concept of freshwater protected areas (FPAs) for minimising the disturbance on freshwater ecosystems suggested by Suski and Cooke (2006) might be useful. A new model of fish conservation in harmony with fishing dependent communities should also be developed in near future for sustainable development. 


\section{Acknowledgements}

Author is thankful to Prof. Kjell Nilssen, Norwegian University of Science and Technology for review of the manuscript. Thanks to Mr. S.K. Wagle, Mr. J.D. Bista, Mr. S.R. Basnet, Dr. A. Baidya, Ms. N. Pradhan, Ms. A. Raymajhi and several other colleagues who contributed to prepare this manuscript. Partial fund for this study was supported by Nepal Agricultural Research Council and Fish Farming Project of Norwegian-Nepal Government.

\section{References}

Allan, J.D., R. Abell., Z. Hogan., C. Revenga., B.W. Taylor., R.L. Welcomme \& K. Winemiller. 2005. Overfishing of inland waters. BioScience 55: 1041-1051.

Allen, D.J., S. Molur \& B.A. Daniel. 2010. The status and distribution of freshwater fishes in the eastern Himalayas. Cambridge, UK and Glands Switzerland: IUCN, Cambatore, India Zoo Outreach Organization.

APP. 1995. Agriculture Perspective Plan (1995-2015), Agriculture Project Services. Centre, Kathmandu and John Mellor Associates. Inc. Washington DC.

Bart, A. 2002. Conservation of fish genetic diversity : need for development of a cryogenic genebank in Bangladesh, pp. 107-110. In: Penman, D, J,, Hussain, M. G., McAndrew, B. J., \& Mazid, M. A. (eds). Proceedings of a workshop on genetic management and improvement stratgees for exotic carps in Asia. 12-14, February 2002, Bangladesh.

Cowx, I.G. 2002. Analysis of threats to freshwater fish conservation: past and present challenges. In: Collares-Pereira, M. J., Cowx, I. G., Coelho, M. M. (Eds.), Conservation of Freshwater Fishes : Options for the Future. Fishing News Books, Blackwell Science, Oxford, pp. 201-220.

Edds, D.R. \& H.H. Ng. 2007. Additions to the Ichthyo fauna of Nepal, with a redescription of Neoeucirrhichthys maydelli (Teleostei: Cobitidae). Ichthyol. Explor. Freshwaters: 125132.

Gibson, G.P \& R.S.V. Pullin. 2005. Conservation of livestock and fish genetic resources, consultative group on international agricultural research science council, Joint report of two studies commissioned by the CGIAR systems p. 95.

Gozlan, R.E. 2008. Introduction of non-native freshwater fish: is it all bad? Fish and Fisheries, 106-115.

Gurung T.B. 2005. Responsible introduction of alien fish and biodiversity in southern Nepal, genetics and biodiversity, Aquaculture Asia. 10(2): 13-15.

Gurung, T.B. \& A.P. Baidya. 2012. Ex-situ breeding performance using pond reared broods of endangered Himalayan mahseer (Tor putitora) in Nepal, eds. Chettri, N; Sherchan, U; Chaudhary, S; Shakya, B (eds) Mountain biodiversity conservation and management: Selected examples of good practices and lessons learned from the Hindu Kush Himalayan region. ICIMOD Working Paper 2/2012. p 6-8.

Gurung, T.B. 2003. Traditional fishers works to save fish species in Nepal's lake. EFN News, Russell E Train, Education for Nature, pp 1 and 5. Education for nature Program World Wildlife Fund, Washington DC 20037-1132, USA

Gurung, T.B. 2007. Restoration of small lakes through cooperative management: A suitable strategy for poverty-laden areas in developing countries? Lakes and Reservoir: Research and Management 12: 237-246. 
Gurung, T.B. 2011. Prospects of cold water fisheries in high altitude wetlands, proceedings of the $8^{\text {th }}$ National workshop on livestock and fisheries research, NARC. pp. 1-9.

Gurung, T.B., A. Rayamajhi, G. Lamsal, R.P. Dhakal \& S.R. Basnet. 2011b. Mid hill river fish and fisheries: resilience to food and nutritional security among hill communities in upper Trishuli, Nepal, p 10-20, Proceedings of the $8^{\text {th }}$ national workshop on Livestock \& Fisheries Research, Nepal Agricultural Research Council

Gurung, T.B., A.P. Baidya \& S.R. Basnet (in press) Promoting fish hatcheries for mitigating impact on native fish biodiversity and stock in regulated rivers, paper presented in ECOPRINT Journal.

Gurung, T.B., P.K. Pokharel \& I. Wright. 2011a. Climate change: Livestock Sector Vulnerability and adaptations in Nepal. Proceedings of consultative technical workshop on Kathmandu, Nepal, Nepal Agricultural Research Council, PO Box 5459, Singh Durbar Plaza.

HMGN/MFSC. 2002. Nepal Biodiversity Strategy, Ministry of Forests and Soil Conservation. HMG, Nepal, p 132.

IDRC. 2007. Research needs in sustaining the aquaculture sector in Asia-Pacific to year 2025 and beyond. A report of the workshop funded by IDRC, Canada, June $4^{\text {th }}$ to $7^{\text {th }} 2007$, Rayong, Thailand, p 163.

IUCN. 2004. A review of the status and threats to wetlands of Nepal. IUCN Wetlands Resources Programme.

Jana, S. 2007. An indigenous fishing minority's movement in Chitwan National Park Nepal, working towards environmental justice, International Center for Integrated Mountain Development (ICIMOD) Kathmandu, Nepal, p 66.

Jha, B.R., H. Waidbacher, S. Sharma \& M. Straif. 2007. Study of the Dams in Different Rivers of Nepal Showed More Severe Impact in Upstream Compared to Downstream, International Conference on Small Hydropower - Hydro Sri Lanka, 22-24 October 2007; p 1-9.web: www.ahec.org.in

KGFH. 2005-06. Annual Report, Kali Gandaki Fish Hatchery: a joint collaboration between Nepal Electricity Authority and Nepal Agricultural Research Council, p 31.

Lysne, S.J., K.E. Perez, K.M. Brownn, R.L. Minton \& J.D. Sides. 2008. A review of freshwater gastropod conservation: challenges and opportunities, J. N. Am. Benthol. Soc. 27(2): 463-470.

Lysne, S.J., K.E. Perez, K.M. Brown, R.L. Minton \& J.D. Sides. 2008. A review of freshwater gastropod conservation: challenges and opportunities, J. N. Am. Benthol. Soc., 227(2): 463-470.

MFSC. 2006. Nepal: Third national report to the convention on biological diversity. HMG, Ministry of Forests and Soil Conservation, Kathmandu, pp. 180.

NARC. 2011. Meeting Nepal's food and nutrition security goals through agricultural science \& technology, NARC's strategic vision for agricultural, published by Nepal Agricultural Research Council, p 56.

Ng, H.H. \& D.R. Edds. 2004. Batasio macronotus, a new species of Bagrid cat fish from Nepal (Teleostei: Bagridae). Ichthyol. Explor. Freshwaters. 15: 295-307.

Ng, H.H. \& D.R. Edds. 2005a. Two new species of Erethistoides (Teleostei : Erethistidae) from Nepal. Ichthyol. Explor. Freshwaters 16(3): 239-248. 
Ng, H.H. \& D.R. Edds. 2005b. Two new species of Pseudechensis rheophilic, cat fish (Teleostei: Sisoridae) from Nepal. Zootaxa 1047:1-19.

Pascual, M., P. Macchi, J. Urbanski, F. Marcos, C.R. Rossi, M. Novara, P.D. Arcipete. 2002. Evaluating potential effects of freshwater fish from incomplete species presenceabsence data. Biological invasion 4: 101-113, Kluwer Academic Publishers.

Rajbanshi, K.G. (in prep). Fishes of Central Himalaya Nepal, paper submitted in workshop organized by Nepal Agricultural Research Council held in Godawari Fisheries Research Division

Rajbanshi, K.G. 1982. A general bibliography on fish and fisheries of Nepal Royal Nepal Academy of Science and Technology, Kathmandu, Nepal, 96 p.

Rajbanshi, K.G. 2005. Review on current taxonomic status and diversity of fishes in Nepal. Royal Nepal Academy of Science and Technology (RONAST). Occasional paper No. 10. $41 \mathrm{pp}$.

Shrestha, J. 1981. Fishes of Nepal. Curriculum Development Center, Tribhuvan University, Kathmandu, $318 \mathrm{pp}$

Shrestha, J. 2011. Threat status of indigenous fish species of Nepal (Rough Draft), A paper presented in consultative workshop on conservation of native fishes in Nepal at Fisheries Research Division, Godawari on $4^{\text {th }}$ July 2011.

Shrestha, J., D.M. Singh \& T.B. Saud. 2009. Fish diversity of Tamor River and its major tributaries of eastern Himalayan Region of Nepal. Nepal Journal Science and Technology 10: 219-223.

Shrestha, T.K. 2007. Conservation and management of fishes in the large Himalayan Rivers of Nepal.

Shrestha, T.K. 2008. Fish diversity of Nepal and potentiality of indigenous fishes for future development of aquaculture. Paper presented in workshop on indigenous fish stock and livelihood in Nepal held at FRD Godawari in 2008.

Suski, C.D. \& J. Cooke. 2006. Conservation of aquatic resources through the use of freshwater protected areas: opportunities and challenges, Biodivers Conserv. DOI 10.1007/s10531006-9060-7

Thapa, I \& B.R. Dahal 2009. Sustainable wetland management for wildlife and people of Koshi Tappu Wildlife Reserve. Ban ko Jankari, special issue, p 36-39; web page www.nepjol.info/index.php/BANKO/article/download/2210/2032

Thompson, C. 2009. New species discoveries, the eastern Himalaya, where world collide, WWF,

Wagle, S.K., T.B. Gurung, N. Pradhan \& A. Raymajhi. 2011. Climate change implication for fisheries and aquaculture in Nepal, In: Gurung T. B., P. K. Pokharel \& I. Wright. 2011. (eds), Proceedings of the workshop on climate change : livestock sector vulnerability and adaptation in Nepal. 